\title{
Analysis of Adaptive Response of Maize (Zea mays) Varieties from DR-Congo to Water Stress
}

\author{
Jean Pierre Kabongo Tshiabukole1,2, Amand Mbuya Kankolongo, ${ }^{1,2}$, Gertrude Pongi Khonde ${ }^{1,2}$, \\ Antoine Mumba Djamba ${ }^{2}$, Roger Kizungu Vumilia ${ }^{1,3}$, Kabwe Nkongolo ${ }^{4}$
}

${ }^{1}$ National Institute for Research and Agronomic Studies (INERA), Kinshasa, Congo

${ }^{2}$ Universite Nationale Pedagogique (UPN), Kinshasa, Congo

${ }^{3}$ Faculty of Agronomy, University of Kinshasa, Kinshasa, Congo

${ }^{4}$ Department of Biological Sciences, Laurentian University, Sudbury, Canada

Email: *knkongolo@laurentian.ca

How to cite this paper: Tshiabukole, J.P.K., Kankolongo, A.M., Khonde, G.P., Djamba, A.M., Vumilia, R.K. and Nkongolo, K. (2017) Analysis of Adaptive Response of Maize (Zea mays) Varieties from DRCongo to Water Stress. American Journal of Plant Sciences, 8, 2282-2295.

https://doi.org/10.4236/ajps.2017.89153

Received: May 5, 2017

Accepted: August 19, 2017

Published: August 22, 2017

Copyright $\odot 2017$ by authors and Scientific Research Publishing Inc This work is licensed under the Creative Commons Attribution International License (CC BY 4.0).

http://creativecommons.org/licenses/by/4.0/

\begin{abstract}
Maize production in tropical Africa is often negatively affected by drought. The main objectives of the present study were to 1 ) analyze the impact of water stress on the agro-morphological performance of two varieties of Quality Protein Maize (QPM) compared to two normal maize varieties and 2) assess their adaptive response in contrasting water environments. Agro-morphological responses to water deficiency of maize (Zea mays L.) were assessed in controlled experiments using four maize varieties, two normal maize (Zm725 and Mus1) and two quality protein maize (Mudishi1 and Mudishi3) varieties. They were subjected to three water regimes $(100 \%, 60 \%, 30 \%$ water retention capacity) at the beginning of the bloom stage, using a Fischer block design with four replications. Significant differences $(p<0.05)$ among varieties, water regimes and their interactions for plant growth and production parameters were observed. Reduction of water supply to plants caused changes in aerial and underground plant growth. Plant stem height, foliar expansion, and root system development characterizing vegetative growth showed variation in varietal response to water regimes. Mus1 (normal maize variety) was the best adapted to variations in water regimes because they developed an important root volume to adapt to the effects of water deficit while maintaining their morphological and productive characteristics.
\end{abstract}

\section{Keywords}

Maize (Zea mays L.), Drought Resistance, Water Stress, Leaf Area Index (LAI), Quality Protein Maize (QPM), DR-Congo 


\section{Introduction}

Drought is one of the limiting factors inmaize (Zea mays L.) production. Indeed, maize growth and yield like most tropical plant species are often negatively affected by drought. Even in areas where rainfalls provide an annual average of $2600 \mathrm{~mm}$ of water, soil water reserves can decrease sharply during the dry season and limits vegetation growth [1]. Maize is sensitive to environmental stresses during flowering period [2] [3] [4].

Several studies have described to the effects of drought on plants [5] [6]. The effects drought on an annual scale depends on its starting period in relation to the crop stage and its duration. Water stress affects several physiological and morphological traits such as leaf temperature regulation [6] [7], stomatal conductance, leaf area [8], as well as photosynthesis [5] [9].

Decrease in water content in plant results in reduced growth of different organs, even before the photosynthesis process is affected [10]. In maize (Zea mays L.), the decrease of $50 \%$ in grain yield is associated with a water deficit during male flowering.

Analysis of agro-morphological characteristics, might contribute to our understanding of crop coping mechanism(s) to water deficit. Hence the objectives of the present study were to 1) analyze the impact of water stress on the agromorphological performance of two varieties of QPM compared to two normal maize varieties and 2) assess their adaptive response in contrasting water environments.

\section{Materials and Method}

\subsection{Experimental Site}

The study was conducted from June to October 2014 at the National Institute of Agronomic Research and Studies (INERA) at Mvuazi research center in the DR-Congo. This center, located at $470 \mathrm{~m}$ altitude, $14^{\circ} 54^{\prime}$ east longitude and $5^{\circ} 21^{\prime}$ latitude south, is characterized by Aw4 climate type with annual rainfalls ranging from $800 \mathrm{~mm}$ to $1200 \mathrm{~mm}$ and temperature ranging between $22^{\circ} \mathrm{C}$ and $30^{\circ} \mathrm{C}$.

\subsection{Plant Material}

Four maize (Zea mays L.) varieties including two genetically improved varieties of Quality Protein Maize (QPM) named Mudishi1 and Mudishi 3, one genetically improved variety of normal maize (Mus1) and an exotic variety (ZM725) were used for this study. These seeds were obtained from INERA (for Mudishi 1, Mudishi 3, and MUS 1) and the International Center of Maize and Wheat Improvement (CIMMYT) of Zimbabwe (for ZM725). The ZM725 variety has been tested in semi-arid areas for its drought tolerance and was used as a reference.

\subsection{Experimental Method}

All the varieties were grown under shelters in a transparent polyvinyl roof, in PVC pots of $50 \mathrm{~cm}$ in depth and $25 \mathrm{~cm}$ in diameter. These pots were filled with a 
non-leached tropical ferruginous soil with an apparent density of $1.64 \mathrm{~g} / \mathrm{cm}^{3}$ and a retention capacity $(\mathrm{RC})$ of $130 \mathrm{~mm}$ per meter of depth.

Sowing of two maize seeds per pot took place after application of $500 \mathrm{ml}$ of a solution of the mineral fertilizer NPK (17-17-17) at a concentration of $2 \mathrm{~g} / \mathrm{L}$ in each pot. The spacing was carried out at 14 days after sowing and consisted in maintaining one vigorous plant per pot.

Prior to the application of treatments (water regime-WR), each pot received $1500 \mathrm{ml}$ of water every week until the beginning of the blooming stage. The pots were then separated into three batches corresponding to the following water regimes:

$-100 \%$ retention capacity $(\mathrm{RC})$ : the plants were regularly watered at $100 \% \mathrm{RC}$.

$-60 \%$ retention capacity $(\mathrm{RC})$ : the plants were watered regularly at $60 \% \mathrm{RC}$,

$-30 \%$ retention capacity $(\mathrm{RC})$ : the plants were watered regularly at $30 \% \mathrm{RC}$.

The experimental design consisted in four Fisher blocks with 3 replications and three water regimes resulting in 48 experimental units (pots). Each block was repeated twice, which allowed the destructive measurements to be conducted on one of the two replications.

Maximum temperature $\left(\mathrm{T}_{\max }\right)$ varied from $26.0^{\circ} \mathrm{C}$ to $29.7^{\circ} \mathrm{C}$ and the minimum temperature $\left(\mathrm{T}_{\min }\right)$ from $16.5^{\circ} \mathrm{C}$ to $19.6^{\circ} \mathrm{C}$ during the growing period. Relative humidity varied from $68 \%$ to $97 \%$. The photoperiod was $12 \mathrm{~h}$ of light and 12 of dark for most of the days during the trial.

\subsection{Data Collection}

During the growth phase, the following parameters were measured: plant height, green leaf number, leaf area index, root volume, and grain yield. These measurements were made at different growing stages including stem elongation (A), $50 \%$ male flowing (B), 50\% female flowering (C), 50\% ear formation (D), ear filling (silk spike) (E), 50\% ear maturity(F), husk senescence (G), 50\% leaf senescence $(\mathrm{H})$, total senescence (leaves and stems) (I), and grain desiccation (J).

Plant heights were measured using a flat ruler placed between the collar and the sheath of the last fully extended leaf. The number of visible green leaves was determined by counting the leaves with less than $50 \%$ senescent surface. The leaf area index (LAI) was estimated as the one-sided green leaf area per unit ground surface area $\left(\mathrm{LAI}=\right.$ leaf area/ground area, $\mathrm{m}^{2} / \mathrm{m}^{2}$ ). Root volume was measured by comparing the water levels before and after immersing all the roots in a known volume of water. The total biomass was measured with a precision balance after drying all plant (stem, leaves, husk and roots) in an oven for three days. The grain yield was the weight adjusted to $14 \%$ of moisture after harvest.

\subsection{Statistical Analysis}

Data were analyzed using Excel 2007 software. The means were separated ( $p \leq$ 0.05 ) using ANOVA followed by multiple comparison tests for each growth stage using the R and Statistix 8 software for Windows. 


\section{Results}

\subsection{Plant Height (HP)}

Plant growth (Figure 1(a)) shows almost the same elongation at the beginning of the upstream period up to $50 \%$ female flowering for Mus1, and reached its maximum $(202 \mathrm{~cm})$ at $50 \%$ of ear maturity. This variety had a fast growth and therefore a higher stem length than the other three varieties during all stages of growth. ZM725 variety with moderate growth before ears maturity reached its

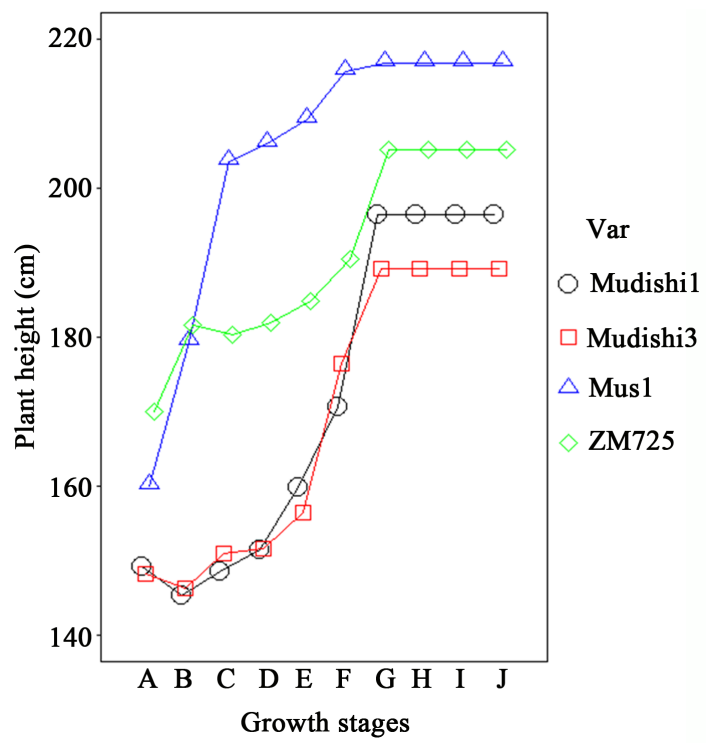

(a)

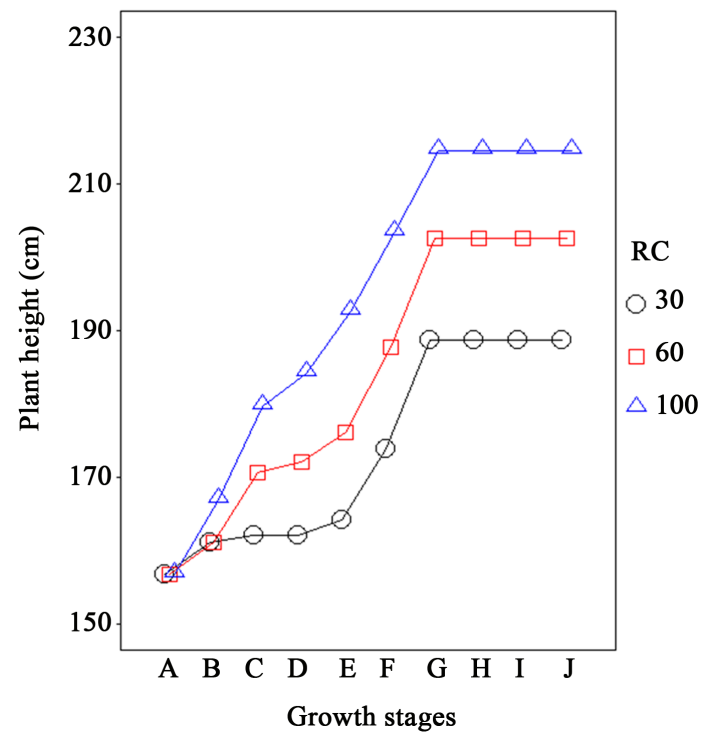

(b)

Figure 1. (a) Evolution of stem growth by varieties in all water regimes combined; (b) Evolution of stem growth by water regime for all varieties. Stem elongation (A), 50\% male flowing (B), 50\% female flowering (C), 50\% ear formation (D), ear filling (silk spike) (E), $50 \%$ ear maturity $(\mathrm{F})$, husk senescence $(\mathrm{G}), 50 \%$ leaf senescence $(\mathrm{H})$, total senescence (leaves and stems) (I), and grain desiccation (J). 
maximum value $(189.10 \mathrm{~cm})$ at the senescence of husk. The QPM varieties $(\mathrm{Mu}-$ dishi1 $(169.19 \mathrm{~cm})$ and Mudishi3 $(166.78 \mathrm{~cm})$, showed a slow development, reaching their maximum height at the senescence of husk.

Figure 1(b) decrypts plant height by water regime (WR). The mean of heights by WR at the end of the assay ranged from $168.27 \mathrm{~cm}$ to $194.15 \mathrm{~cm}$. Analysis of the variance showed a highly significant difference $(p<0.05)$ among the WRs. The treatments were ranked in the following order: $100 \%>60 \%>30 \% \mathrm{RC}$.

\subsection{Number of Visible Green Leaves (NGL)}

The number of visible green leaves per variety (Figure 2(a)) was similar for all varieties (up to $50 \%$ female flowering). After this stage, the onset of foliar senes-

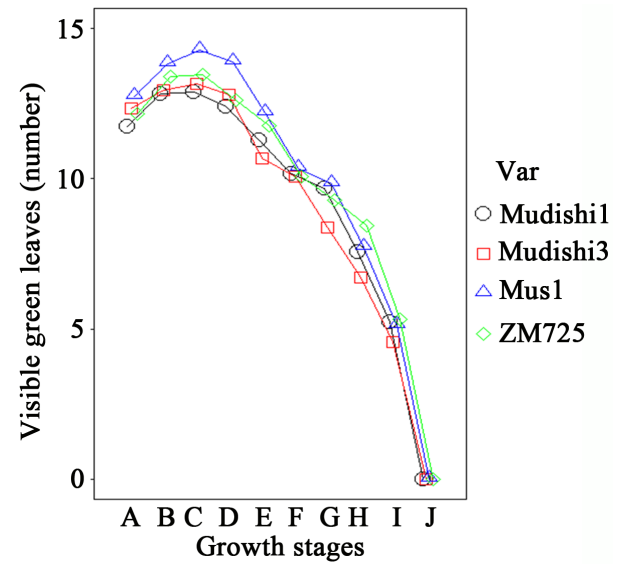

(a)

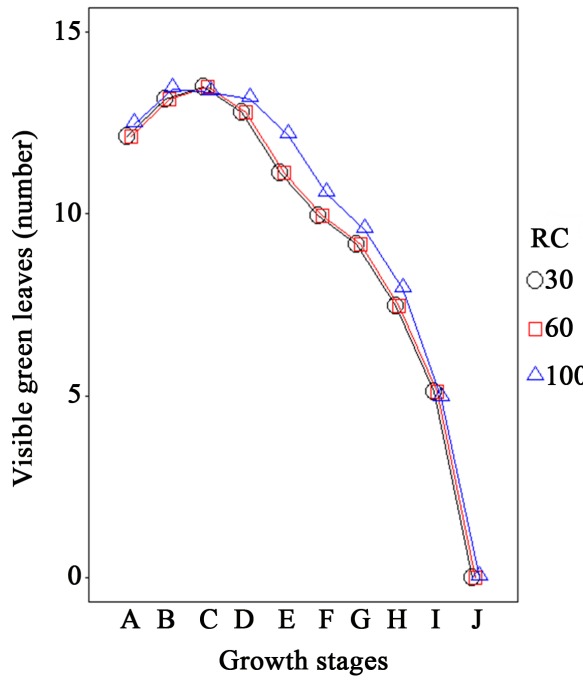

(b)

Figure 2. (a) Evolution of the number of visible green leaves by variety in all water regimes combined; (b) Evolution of the number of green leaves visible by regime for all varieties. RC represents retention capacity. Stem elongation (A), 50\% male flowing (B), 50\% female flowering (C), 50\% ear formation (D), ear filling (silk spike) (E), 50\% ear maturity $(\mathrm{F})$, husk senescence $(\mathrm{G}), 50 \%$ leaf senescence $(\mathrm{H})$, total senescence (leaves and stems) (I), and grain desiccation $(\mathrm{J})$. 
cence was observed. The NGL of Mus1 variety remained significantly higher until ears maturity. After this stage, the NGL for ZM725 became higher until total senescence. The QPM varieties (Mudishi1 and Mudishi3) showed significantly lower NGL throughout the entire growing period. No significant difference $(p<$ $0.05)$ was observed between varieties at ear maturity.

Analysis of water regime (Figure 2(b)) showed that the 100\% RC regime has the highest NGL from the phase of $50 \%$ of ear formation until senescence. Plants treated with $60 \% \mathrm{RC}$ and $30 \% \mathrm{RC}$ regimes showed identical NGLs.

\subsection{Leaf Area Index (LAI)}

The LAI of each variety under all regimes (Figure 3(a)) was estimated as a function of leaf area and density during the test. Mus1 variety recorded the highest LAI values throughout the trial. However, Mudishi 3 showed the lowest LAI from the $50 \%$ female flowering stage until the end of the assay.

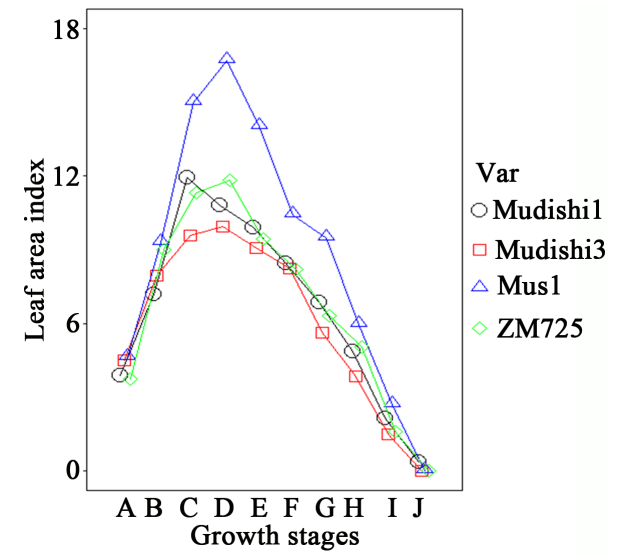

(a)

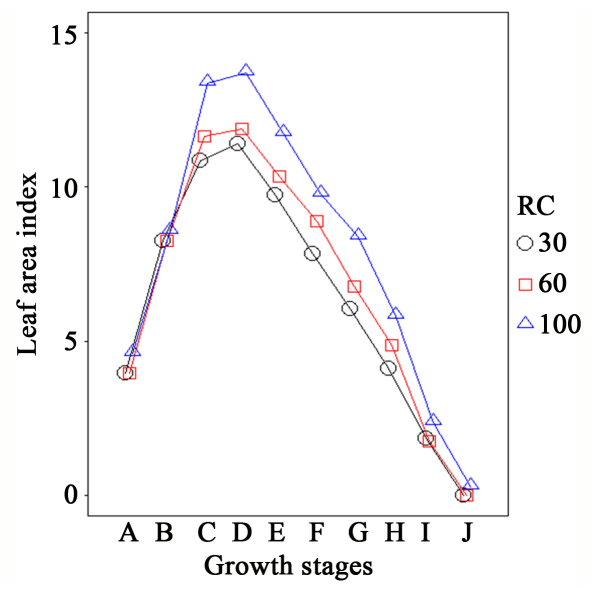

(b)

Figure 3. (a) Evolution of Leaf Area Index (LAI) of variety in all water regimes; (b) LAI evolution by water regime for all varieties. RC represents retention capacity. Stem elongation (A), 50\% male flowing (B), 50\% female flowering (C), 50\% ear formation (D), ear filling (silk spike) (E), 50\% ear maturity (F), husk senescence $(G), 50 \%$ leaf senescence $(\mathrm{H})$, total senescence (leaves and stems) (I), and grain desiccation (J). 
For plants in pots that were watered at $100 \% \mathrm{RC}$, the maximum LAI was recorded at $50 \%$ of ear formation for all varieties. The LAIs were significantly influenced by the water regime (Figure $3(\mathrm{~b})$ ). The $100 \% \mathrm{RC}$ regime resulted in the formation of large LAIs compared to other water regimes. Figure 3(b) shows that LAIs were similar at $50 \%$ of male flowering and decreased significantly at ears maturation and husk senescence and remained at the same level until the end of the crop.

\subsection{Root Volume (RV)}

Root volume of plants per variety (Figure 4(a)) varied substantially among different growing stages (GS). Mus1 had the highest root volume until the end of

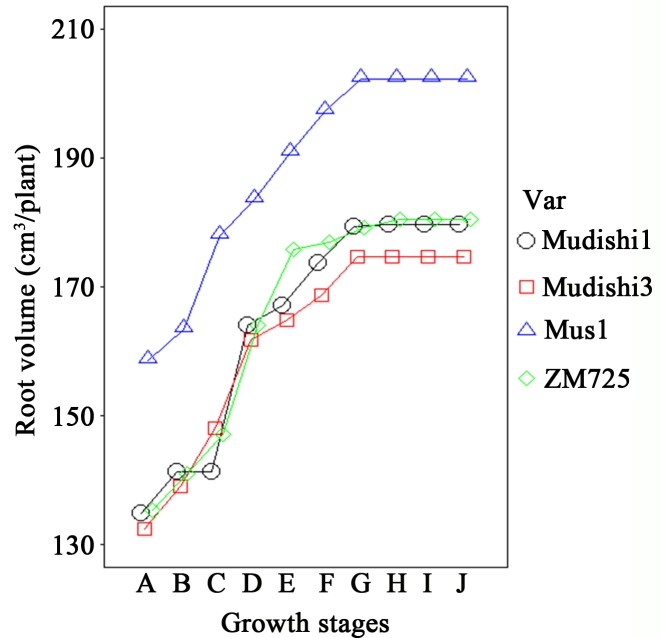

(a)

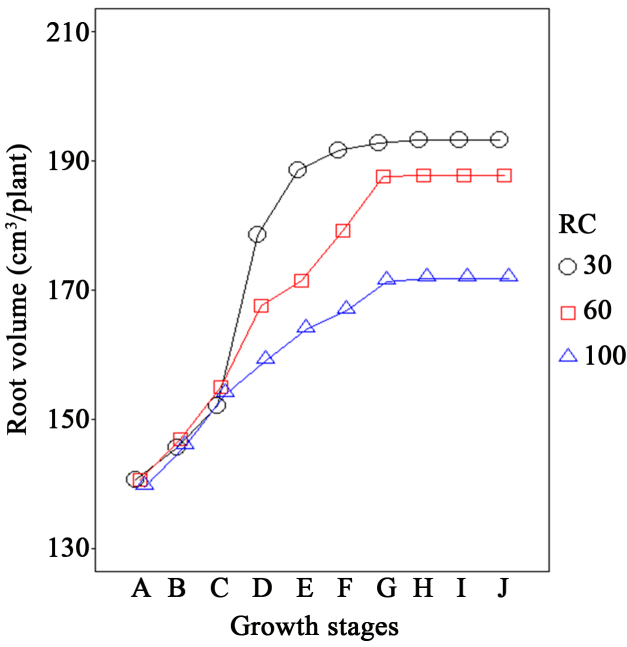

(b)

Figure 4. (a) Evolution of root volume by variety for all water regimes combined; (b) Evolution of root volume by water regime for all varieties. RC represents retention capacity. Stem elongation (A), 50\% male flowing (B), 50\% female flowering (C), 50\% ear formation (D), ear filling (silk spike) (E), 50\% ear maturity (F), husk senescence (G), 50\% leaf senescence $(\mathrm{H})$, total senescence (leaves and stems) (I), and grain desiccation (J). 
the assay. For all varieties, significant increases in root volume were recorded between 50\% female flowering and ear maturing before reaching the final volume.

Variation in root volume based on water regime is described in Figure 4(b). Two subgroups can be identified. In the first group, characterized by the $30 \% \mathrm{RC}$ regime, there is first a linear increase in all plants before female flowering, then an exponential phase pushing the plants to the maximum production until the beginning of the senescence. In the second group that includes the $100 \% \mathrm{RC}$ and $60 \% \mathrm{RC}$, the trends are similar from the beginning of male flowering to the senescence of husk. A significant difference $(p<0.05)$ was observed among the water regimes; the $30 \% \mathrm{RC}$ regime with $195 \mathrm{~cm}^{3} /$ plant positively influenced root production, followed by the $60 \% \mathrm{RC}$ regime with $185.15 \mathrm{~cm}^{3} /$ plant and then the $100 \% \mathrm{RC}$ with $170 \mathrm{~cm}^{3} /$ plant at the end of the test.

\subsection{Grain Yield $\left(\mathrm{g} / \mathrm{m}^{2}\right)$}

Since the test was carried out in a pot, the yield was determined per volume of soil per unit of area. Figure 5(a) shows grain yields recorded for each water regime. In general, significant differences were observed among water regimes. The $100 \% \mathrm{RC}$ regime resulted in an average production of $2101.7 \mathrm{~g} / \mathrm{m}^{2}$ followed by the $60 \%$ RC regime with $1858 \mathrm{~g} / \mathrm{m}^{2}$ and the $30 \%$ RC regime with $1372 \mathrm{~g} / \mathrm{m}^{2}$.

All varieties were significantly affected by the amount of water during the test. Figure 5(b) shows that when 100\% RC was applied, Mus 1 and ZM725 produced the highest yields compared to the two QPM varieties. The switch to lower WR significantly reduced the ZM725 yield by more than $25 \%$ in $60 \%$ RC and more than $40 \%$ in $30 \%$ RC. While QPM varieties have almost retained their yield in $60 \% \mathrm{RC}$, there was a decreaseof grain yields in the $30 \% \mathrm{RC}$ regimen.

\subsection{Biomass (BM)}

Figure 6(a) shows the levels of biomass production for each water regime. Analysis of variance of biomass by water regime revealed significant differences $(p<0.05)$ among treatments. The $100 \% \mathrm{RC}$ regime resulted in the highest biomass $(151 \mathrm{~g} /$ plant $)$ followed by $60 \% \mathrm{RC}(142.85 \mathrm{~g} /$ plant $)$ and 30\% RC (116.67 g/plant).

A significant difference was found between ZM725 and the other three varieties for the water regimes of $60 \% \mathrm{RC}$ and $30 \% \mathrm{RC}$. Its biomass production remained lower than that of Mus1 and the two QPMs. However, no significant difference was observed between Mus1 and the two QPMs in 60\% RC and 30\% RC (Figure 6(b)).

\section{Discussion}

Application of the three water regimes (100\% RC, $60 \%$ RC, and $30 \% \mathrm{RC}$ ) on the four varieties revealed the actual impact of drought on maize growth and the critical plant development phases during which plants are more vulnerable. It 


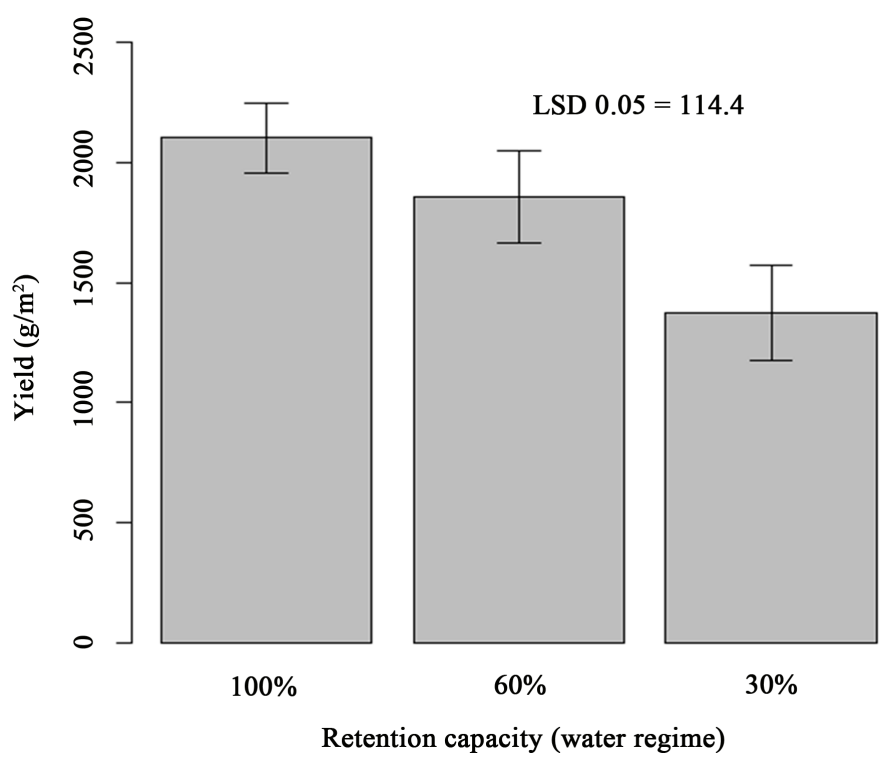

(a)

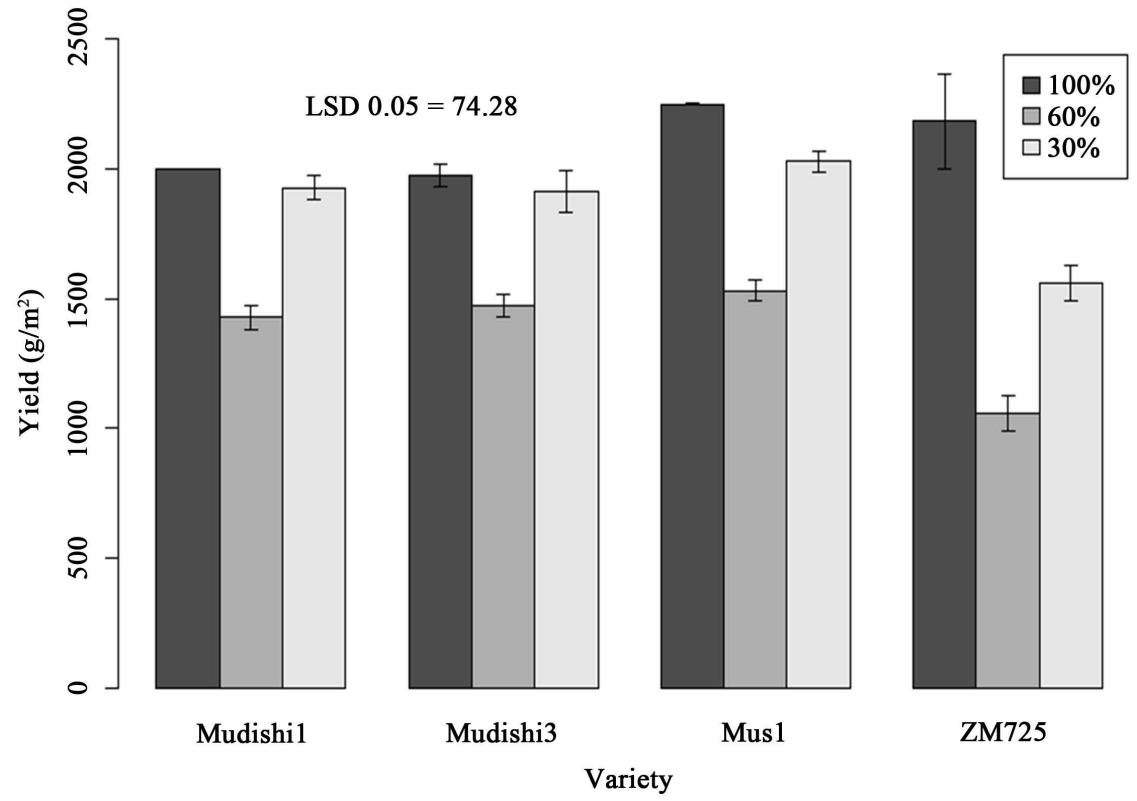

(b)

Figure 5. (a) Average yield by water regime (retention capacity) for all varieties; (b) Yield average per variety by water regimes or retention capacity.

also helped determine if plant's response to water shortage has been specific. Our results showed varietal differences for plant growth and grain yield, two groups of parameters that characterize plant development and production. Hence these four maize varieties have different adaptation mechanism to water availability. A significant decrease in these parameters was observed in the plants at $30 \% \mathrm{RC}$ for all the varieties.

Stem length varied according to the water regime. Similar results were reported by Attia (2007) on cotton crop [11]. They also observed a decrease in 


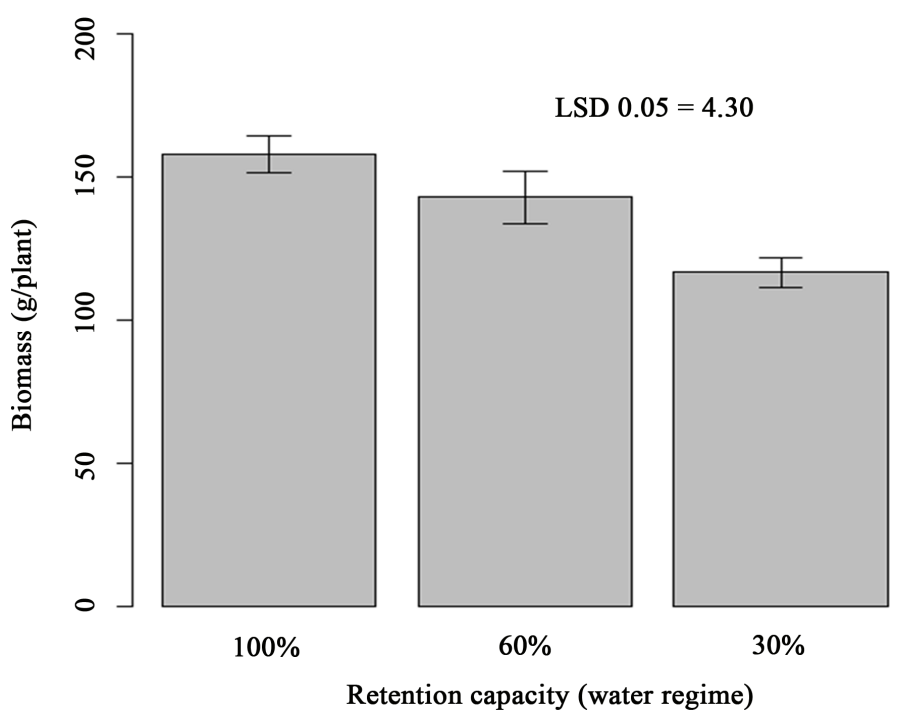

(a)

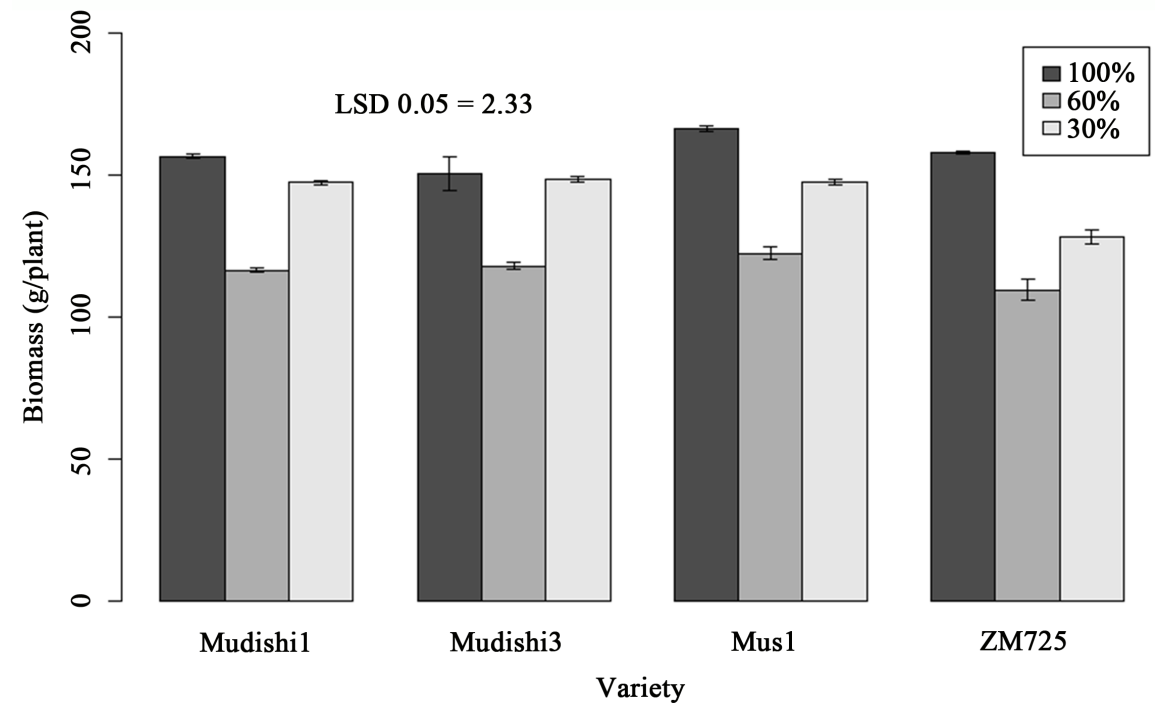

(b)

Figure 6. (a) Biomass average by water regime (retention capacity) for all maize varieties; (b) Biomass average by variety by water regime or retention capacity.

plant size that was associated with irrigation doses of $50 \%$ and $25 \%$ compared to the control that was irrigated at $100 \%$.Stem length and root volumes, two parameters associated with plant growth, showed, firstly, a varietal effect at the end of the test and secondly, a water regime effect. Mus1 and ZM725 varieties showed the longest stem and the largest root volume. These two maize varieties, with good vegetative growth, appeared to be better suited to the normal water regimen, however QPM varieties respond better to stress conditions. A decrease in the amount of water resulted in a significant increase of the root system from male flowering. Magorokosho et al. (2003) showed that this phase of growth is the most vulnerable for maize [12]. Edmeades \& et al. (1995) reported that the estimated loss of yield could range from $21 \%$ to $50 \%$ [13]. Under conditions of 
water deficit, plants increase their water resource through root mining.

Salah and Tardieu, (1997) and Cakir, (2004) showed that leaf surfaces of maize plants subjected to water deficits were smaller than those of well-watered plants [3] [14]. These findings are consistent with those reported by Matthews (1986) and Chartzoulakisa et al. (2002) [15] [16]. Reduction of leaf area by water stress may be due to a decrease in mitotic activity of epidermal cells which results in a reduction in the total number of leaf cells [15]. It may also be due to a reduction in the size of the cell due to anatomical changes [16]. The decrease in leaf area under the limiting water regime is an adaptive plant mechanism to limit leaf transpiration when water conditions become unfavorable. The weak development of the leaf area from the ear filling stage, observed in all the plants, could be explained by a low need of water at the beginning of maturity of the cobs. The reduction in leaf area is less marked when stress is imposed at the vegetative stage. Normal foliar development resumes when plants are watered again.

Significant correlations among different parameters measured were found for different water regimes. This suggests that switching to stress induces variations in different parts of the plant [17] [18] [19]. These results are similar to those reported by Kimani et al (1994), who showed that severe water stress reduced plant biomass in Cajanus cajan from 34\% to 54\% [20]. Sustained growth of the root system under stress would be a factor of resistance to water stress. This phenomenon is explained by the fact that soil usually dries on the surface and roots sink more into the soil in search of water. Indeed, grain yield depends closely on the quantities of water available during the period from an thesis to maturity. The maintenance of high yield under water deficit conditions in certain varieties such as Mus1 and Mudishi3 can be explained by the ability to pump deeply water because of their important root system development. According to Passioura (1977), root system ability to exploit soil water reserves under stress is an effective response to sustain grain production [21]. Kabongo etal., (2016a, 2016b) reported that Mus1 and Mudishi3 varieties were among maize accessions that were moderately sensitive to changes in soil water potential in a field study [22] [23]. Their stress sensitivity index was $<1$.

It has been demonstrated that the most critical period of water supply is between 14 days before and 14 - 21 days after silking [24] [25]. During this period, grain yield is determined and the longer the duration of water stress the more severe is the crop failure [25] [26]. Other studies have demonstrated specific effects of water stress on maize phenology, leaf production, and grain yield varied with varieties [26] [27] [28].

\section{Conclusion}

The objective of this study was to analyze the impact of water stress on the agro-morphological performance of two varieties of QPM compared to two other normal maize varieties, and to assess their adaptive response in contrasting water environments. The four varieties that were characterized showed different 
adaptation mechanisms to various water regimes. The results revealed that water deficit accentuated at the beginning of flowering influences plant growth and its development. However, this early flowering deficit reduces yield. MUS 1 variety was more adapted to variation to water availability. High-performance varieties will sustain its growth and productivity in areas with low or irregular rainfalls. Hence, the QPM varieties tested in the present study grown in the savanna of southwestern DRC are less vulnerable to the effects of moderate water stress that occurs during plant growing cycle.

\section{Acknowledgements}

This research was conducted through a partnership between "Universite Pedagogique Nationale (UPN)" of Kinshasa (DR-Congo), INERA DR-Congo, and Laurentian University (Ontario, Canada).

\section{Competing Interest}

Authors have declared that no competing interests exist.

\section{References}

[1] Cornic, G. and Massacci, A. (1996) Leaf Photosynthesis under Drought Stress. In: Baker, N.R., Ed., Photosynthesis and the Environment, Kluwer Academic Publishers, New York, 347-366.

[2] Pandey, R.K., Maranville, J.W. and Admou, A. (2000) Deficit Irrigation and Nitrogen Effects on Maize in a Sahelian Environment: I. Grain Yield and Yield Components. Agricultural Water Management, 46, 1-13. https://doi.org/10.1016/S0378-3774(00)00073-1

[3] Çakir, R. (2004) Effect of Water Stress at Different Development Stages on Vegetative and Reproductive Growth of Corn. Field Crops Research, 89, 1-16. https://doi.org/10.1016/j.fcr.2004.01.005

[4] Farré, I. and Faci, J.M. (2006) Comparative Response of Maize (Zea mays L.) and Sorghum (Sorghum bicolor L. Moench) to Deficit Irrigation in a Mediterranean Environment. Agricultural Water Management, 83, 135-143. https://doi.org/10.1016/j.agwat.2005.11.001

[5] Yang, H.S., Dobermann, A., Lindquist, J.L., Walters, D.T., Arkebauer, T.J. and Cassman, K.G. (2004) Hybrid-Maize-A Maize Simulation Model That Combines Two Crop Modeling Approaches. Field Crops Research, 87, 131-154. https://doi.org/10.1016/j.fcr.2003.10.003

[6] Luquet, D., Vidal, A., Dauzat, J., Bégué, A., Olioso, A. and Clouvel, P. (2004) Using Directional TIR Measurements and 3D Simulations to Assess the Limitations and Opportunities of Water Stress Indices. Remote Sensing of Environment, 90, 53-62. https://doi.org/10.1016/j.rse.2003.09.008

[7] Patel, N.R., Mehta, A.N. and Shekh, A.M. (2001) Canopy Temperature and Water Stress Quantificaiton in Rainfed Pigeonpea (Cajanus cajan (L.) Millsp.). Agricultural and Forest Meteorology, 109, 223-232. https://doi.org/10.1016/S0168-1923(01)00260-X

[8] Lawlor, D.W. and Cornic, G. (2002) Photosynthetic Carbon Assimilation and Associated Metabolism in Relation to Water Deficits in Higher Plants. Plant, Cell \& En- 
vironment, 25, 275-294. https://doi.org/10.1046/j.0016-8025.2001.00814.x

[9] Tardieu, F. and Simonneau, T. (1998) Variability among Species of Stomatal Control under Fluctuating Soil Water Status and Evaporative Demand: Modelling Isohydric and Anisohydric Behaviours. Journal of Experimental Botany, 49, 419-432. http://www.jstor.org/stable/23695975

[10] Turner, N.C., Wright, G.C. and Siddique, K.H.M. (2001) Adaptation of Grain Legumes (Pulses) to Water-Limited Environments. Advances in Agronomy, 71, 193 231. http://dx.doi.org/10.1016/S0065-2113(01)71015-2

[11] Attia, F. (2007) Effect of Water Stress on the Ecophysiological Behavior and Phenolic Maturity of Vitis vinifera L.: Study of Five Indigenous Varieties of the MidiPyrenées. Toulouse.

[12] Magorokosho, C., Pixley, K.V. and Tongoona, P. (2003) Selection for Drought Tolerance in Two Tropical Maize Populations. African Crop Science Journal, 11, 151162.

[13] Edmeades, G.O., Banziger, M., Chapman, S.C., Ribaut, J.M. and Bolaños, J. (1997) Recent Advances in Breeding for Drought Tolerance in Maize. Springer, Berlin, 63 78. https://doi.org/10.1007/978-94-017-0754-1_5

[14] Salah, H.B.H. and Tardieu, F. (1997) Control of Leaf Expansion Rate of Droughted Maize Plants under Fluctuating Evaporative Demand (A Superposition of Hydraulic and Chemical Messages?). Journal of Plant Physiology, 114, 893-900. https://doi.org/10.1104/pp.114.3.893

[15] Matthews, L.A. (1986) The Effect of Water Stress on the Leaf Area of Cucumis me1o. Master's Thesis, Texas Tech University, Lubbock.

[16] Chartzoulakis, K., Patakas, A., Kofidis, G., Bosabalidis, A. and Nastou, A. (2002) Water Stress Affects Leaf Anatomy, Gas Exchange, Water Relations and Growth of Two Avocado Cultivars. Scientia Horticulturae, 95, 39-50. https://doi.org/10.1016/S0304-4238(02)00016-X

[17] El Fakhri, M., Mahboub, S., Benchekroun, M. and Nsarellah, N. (2010) Effet du Stress Hydrique sur les Caractéristiques d'Enracinement du Blé Dur. Nat. Technol., 6-12.

[18] Fischer, R.A. and Maurer, R. (1978) Drought Resistance in Spring Wheat Cultivars. I. Grain Yield Responses. Australian Journal of Agricultural Research, 29, 897-912. https://doi.org/10.1071/AR9780897

[19] Sawadogo, M., Zombre, G. and Balma, D. (2006) Expression de Différents Écotypes de Gombo (Abelmoschus esculentus L.) au Déficit Hydrique Intervenant Pendant la Boutonnisation et la Floraison. Biotechnology, Agronomy, Society and Environment, 10, 43-54.

[20] Kimani, P.M., Benzioni, A. and Ventura, M. (1994) Genetic Variation in Pigeon Pea (Cajanus cajan (L.) Mill sp.) in Response to Successive Cycles of Water Stress. Plant and Soil, 158, 193-201. https://doi.org/10.1007/BF00009494

[21] Passioura, J.B. (1977) Grain Yield, Harvest Index, and Water Use of Wheat. Journal of the Australian Institute of Agricultural Science, 43, 117-120.

[22] Kabongo, T., Pongi, K., Mumba, D., Kizungu, V., Mbuya, K. and Nkongolo, K. (2016) Evaluation of Maize Sensitivity to Drought in Southwestern Savannah Area of DR. Congo. African J. Agric. Sci. Technol., 4, 812-817.

[23] Kabongo, T., Pongi, K., Mumba, J., Mbuya, K., Kizungu, V. and Nkongolo, K. (2016) Stress Tolerance Indexes of Maize (Zea mays L.) Grown in the Southwestern Savannah in the Democratic Republic of Congo. International Journal of Innova- 
tion and Scientific Research, 26, 355-360.

http://www.ijisr.issr-journals.org/abstract.php?article=IJISR-16-200-03

[24] Singh, B.R. and Singh, D.P. (1995) Agronomic and Physiological Responses of Sorghum, Maize and Pearl Millet to Irrigation. Field Crops Research, 42, 57-67. https://doi.org/10.1016/0378-4290(95)00025-L

[25] Madhiyazhagan, R. (2005) Modeling Approach to Assess the Impact of High Temperature and Water Stress on Dry Land Maize. Ph.D. Thesis, University of Queensland, Brisbane.

[26] Song, Y., Birch, C., Qu, S., Dohert, A. and Hanan, J. (2010) Analysis and Modelling of the Effects of Water Stress on Maize Growth and Yield in Dryland Conditions. Plant Production Science, 13, 199-208. https://doi.org/10.1626/pps.13.199

[27] Cavero, J., Farre, I., Debaeke, P. and Faci, J.M. (2000) Simulation of Maize Yield under Water Stress with the EPICphase and CROPWAT Models. Agronomy Journal, 92, 679-690. https://doi.org/10.2134/agronj2000.924679x

[28] Birch, C.J., Vos, J. and Van der Putten, P.E.L. (2003) Plant Development and Leaf Area Production in Contrasting Cultivars of Maize Grown in a Cool Temperate Environment in the Field. European Journal of Agronomy, 19, 173-188.

https://doi.org/10.1016/S1161-0301(02)00034-5

Submit or recommend next manuscript to SCIRP and we will provide best service for you:

Accepting pre-submission inquiries through Email, Facebook, LinkedIn, Twitter, etc. A wide selection of journals (inclusive of 9 subjects, more than 200 journals) Providing 24-hour high-quality service User-friendly online submission system Fair and swift peer-review system Efficient typesetting and proofreading procedure Display of the result of downloads and visits, as well as the number of cited articles Maximum dissemination of your research work

Submit your manuscript at: http://papersubmission.scirp.org/

Or contact ajps@scirp.org 